Article

\title{
Political Marketing Strategies to Foster the Sustainability of Private Transnational Organisations: The Case of the IASB
}

\author{
Barbara Masiello, Nicola Moscariello * and Pietro Fera \\ Department of Economics, University of Campania 'Luigi Vanvitelli', 81043 Capua, Italy; \\ barbara.masiello@unicampania.it (B.M.); pietro.fera@unicampania.it (P.F.) \\ * Correspondence: nicola.moscariello@unicampania.it
}

Received: 21 June 2018; Accepted: 23 July 2018; Published: 28 July 2018

\begin{abstract}
By analysing the case of the International Accounting Standards Board (IASB), this paper aims at assessing the role that political marketing strategies might play to increase the sustainability of private transnational organisations. This paper proposes an integrated conceptual model that draws together political branding theory and political relationship marketing. The proposed model shows how political marketing strategies may help a global standard setter, as well as other private transnational organisations, in achieving higher legitimacy and sustainability in the long-term. By relying upon such a model, an explanatory case study of the IASB is then conducted, providing anecdotal evidence about the IASB's current political marketing behaviour. By adopting an interdisciplinary interpretative lens, this paper contributes to literature in addressing a theme almost neglected-namely, the role of political marketing strategies in increasing legitimacy and sustainability of transnational organisations, such as global standard setters-notwithstanding the emerging effort made in this direction by private global organisations operating in complex environments, including the IASB. Implications for political marketing theory are also discussed. As to the practical implications, this paper suggests the political marketing strategies and tools that private transnational organisations should adopt to foster their sustainability in the long-term.
\end{abstract}

Keywords: political marketing strategies; sustainability; branding; relationship marketing; private transnational organisations; IASB; legitimacy

\section{Introduction}

Recent academic debate has underlined that the concept of legitimacy is central for private transnational organisations. Indeed, transnational organisations often represent only a small part of the stakeholders potentially affected by their rules. Therefore, the lack of a direct 'through-election' democratic legitimacy characterizing these bodies questions the authority of their political relevant activities and threatens their long-term growth and sustainability [1,2]. The brief considerations above appear to be particularly appropriate for the International Accounting Standards Board (IASB). The IASB is not only a private and independent standard-setting body, it is also a global organisation not accountable to any domestic democratically legitimated legislative or administrative institutions [3]. The transnational governance of the IASB significantly weakens its legal legitimacy and makes it subject to political influence, particularly in case of environmental turmoil [4]. Indeed, during the global financial crisis, the IASB faced considerable pressure to change the standard-setting agenda, suffering a re-balance of power in favour of political interests in order to preserve its role in Europe [5,6].

Therefore, a deep analysis of the IASB's legitimacy sources is essential in order to understand the sustainability of the transnational standard setter and its growth opportunities across the world. 
In this regard, mainly drawing from regulatory theory, the academic literature has long argued on the importance of the IASB governance structure and on the procedures it follows to draw up its standards (i.e., procedural legitimacy). The competence and technical expertise of the IASB members also represent a fundamental factor contributing to the IASB legitimacy (i.e., substantial legitimacy) [7]. Surprisingly, little research attention has been addressed toward the political marketing strategies adopted by the IASB in order to retain and strengthen its procedural and substantial legitimacy. Several contributions deepen the rhetorical techniques adopted by the standard setters in order to persuade stakeholders about the fairness and usefulness of their standards [8-10]. However, none of these makes a step forward by considering the rhetorical devices as part of operational tools within a wider strategic marketing process, where 'consumers' (i.e., financial statement users) are elevated from being passive recipients of a standard setter's ideology to playing an interactive role in the production of the accounting standards.

To fill this gap, this paper proposes a conceptual model that indicates how political marketing strategies [11] can be implemented by a private transnational organisation, such as the IASB, to adapt itself to the changes and the demands of the external environment and, in so doing, to increase its substantial and procedural legitimacy as a global standard setter. By conducting an explorative analysis, this paper also presents some anecdotal evidence about the branding marketing strategies and the relationship marketing strategies currently adopted by the IASB, in order to offer a concrete response to the accounting constituents' specific requests and to increase the effectiveness of its institutional activity. After all, higher attention by the IASB towards marketing competences can be traced to the appointment of Mr Hans Hoogervorst as chairman, who, unlike the previous chair (Sir David Tweedie, IASB chairman until July 2011), was not a trained accountant but a former politician with strong skills in international relations.

The article proceeds as follows. The next section outlines the foundations of the legitimacy of the IASB and the important criticisms recently emerged in this regard, so highlighting the potential interpretative contribution that political marketing research could provide. Section 3 develops a conceptual model for assessing the role of political marketing strategies in increasing the legitimacy and the sustainability of private transnational organisations, such as the IASB. Section 4 presents a case study analysis of the IASB's political marketing behaviour in the light of our conceptual framework. Section 5 concludes, highlighting the limitations of the study and giving suggestions for theory and practice.

\section{The Foundations and Limitations of the IASB Legitimacy}

The setting of standards is not a mere technical matter, but is also a process with political consequences [12]. Therefore, the independence of the standard-setting due process and the neutrality of the boards' technical guidance are constantly exposed to a risk of regulatory capture [13-15]. Then, the analysis of the accounting standard setter's legitimacy sources is crucial to understand the sustainability of the organisation in a complex global environment.

According to Johnson and Solomons [16], the institutional legitimacy of a standard setter is a function of three conditions: (i) sufficient authority condition; (ii) substantive due process condition; and, (iii) procedural due process condition. The sufficient authority requires a clear mandate of authority and competence from legislative or administrative agencies. The substantive due process exists if the standard setter can justify each exercise of its authority and provides adequate rationale for its standards. The procedural due process condition is met when interested parties are given sufficient opportunities to influence the rule-making process [17,18].

As to the first condition (sufficient authority), the IASB has always directed its efforts to gain political support as the world's standard-setter for financial markets [19,20]. The acknowledgement of the IASC (International Accounting Standards Committee, that is the IASB's predecessor) as a 'global accounting standard setter' by the International Federation of Accountants (IFAC) in 1982 and by the International Organisation of Securities Commission (IOSCO) in 2000 have been fundamental 
steps in this direction. The U.S. Securities and Exchange Commission (SEC) decision in 2007 to drop the reconciliation requirements for foreign registrants adopting the International Accounting Standards (IAS/IFRS) also represents an important development in favour of the harmonization process. Yet, a pivotal event in the IASB's history has been the EU's endorsement of the IAS/IFRS (Regulation 1606/2002), with a clear mandate to the international standard setter to produce a common set of accounting standards for consolidated financial reporting that encouraged many other countries to take similar measures in the following years [21].

Since its inception, the IASB has also paid great attention to factors enhancing its substantial and procedural legitimacy [22]. Indeed, the credibility of the IASB is strongly correlated-on the one hand-on to the perceived independence, expertise, and capacity of its personnel and on the quality of its results (i.e., substantial, expertise-based, output legitimacy), and—on the other hand-on its ability to involve affected parties in the rule-making process and to assure stakeholders regarding the fairness of the procedure in which inputs are transformed into outputs (i.e., participatory and procedural input legitimacy) [23]. To this end, during the last decades, the IASB has been involved in important technical projects, effective governance reforms and valuable innovations in its standard-setting procedures.

The issue of the 'Framework for the Preparation and the Presentation of Financial Statements' in 1989 [24] has certainly played a fundamental role in the IASB's quest for substantial legitimacy. In fact, apart from the explicit role of setting up the basic concepts for assisting the Board in the development of its accounting standards ([24], p. 77), the development of a Conceptual Framework represents 'a strategic manoeuvre for providing legitimacy' ([25], p. 89) and an instrument for 'rising the moral tone of the profession' ([26], p. 255) (see also: [27,28]). Hence, the Conceptual Framework is not only a technical tool for the IASB, but is also a way for the standard setter to be better armed to promote its standards and preserve its independence [29].

As to governance reforms, it is noteworthy to remember that in 2001 the IASC transformed itself into a foundation (the IFRS Foundation) and left its operational activity to the IASB. The Foundation finances the IASB and appoints its members, strengthening in this way the independence and the authority of the standard setting body. Moreover, in 2009 a Monitoring Board was also established to oversee the IFRS Foundation and to provide a formal link between the IFRS Foundation Trustees and public authorities, with the intention to 'replicate — on an international basis—the link between accounting standard-setters and those public authorities that have generally overseen accounting standard-setters' ([30], p. 9).

Finally, when the IFRS Foundation was formed, the due process requirements 'built on the principles of transparency, full and fair consultation-considering the perspectives of those affected by IFRSs globally - and accountability' were also formalized, in order to guarantee a transparent and independent elaboration of the accounting standards and to ensure that all the parties concerned make their voices heard ([31], p. 5). At the moment, the due process steps mandatorily include: (a) debating any proposals in one or more public meetings; (b) exposing for public comment a draft of any proposed new Standard, with minimum comment periods; (c) considering in a timely manner those comment letters received on the proposals; (d) considering whether the proposals should be exposed again; (e) reporting to the Advisory Council on the technical programme, major projects, project proposals and work priorities; (f) ratification of an Interpretation by the IASB. In addition, other steps are not mandatory: (i) publishing a discussion document; (ii) establishing consultative groups; (iii) holding public hearings; (iv) undertaking field work. However, a non-compliance with them would require an explanation (comply or explain step).

As a result of the reforms briefly mentioned above, the IASB has been cited by some as one of the most effective and accountable of the transnational regulatory bodies [32,33].

However, despite the unquestionable political successes, the advanced technical expertise and the dramatic structural and procedural improvements, the IASB's political, substantial, and procedural legitimacy has been strongly questioned $[7,23,34,35]$. 
The transnational private governance of the IASB has often been identified as the main factor limiting the political legitimacy, hence the authority condition of the global standard setter. Indeed, the delegation of rule-making authority to private bodies has a long domestic tradition, particularly with regard to technical standards [36,37]. However, in the case of transnational organisations, the long chains of delegation from the will of the people (as expressed in electoral or other processes of citizen participation) to the transnational body raises concerns over the accountability process and lessens the transparency of the decision-making activity $[23,38]$.

The democratic legitimacy deficit ascribed to the IASB also undermines the substantial legitimacy based on the technical expertise of the global standard setter. In fact, the redistributive effects unquestionably associated with the standard-setting process and the absence of an objectively superior set of standards provoke social implications, questioning the neutrality and the independence of the rule-maker [35]. In other terms, in the absence of substantial political support, the technical expertise risks being interpreted as an instrument to promote accounting professionals' ideologies in the pursuit of their own interests $[34,39]$.

These considerations explain the considerable efforts that the IASC Foundation has made to improve the due process of the IASB. Indeed, the development of the due process compensates for the lack of formal accountability to an external public principal, especially in a transnational context characterized by the absence of a judicial authority [40,41]. However, the due process is not immune to severe drawbacks that significantly weaken its legitimacy functions. Respondents to the IASB discussion papers and exposure drafts are not a representative sample of the population of financial information users and have not been randomly selected [7]. Moreover, an active participation in the deliberative process requires financial resources and technical competence that considerably narrows the number of participants [41]. Finally, at the end of the due process, the IASB can still make its own choices counter to the majority of the received comments [42]. For this reason, the IASB due process has been compared to 'a vote on highly technical questions, participation in which must be paid for, and the result of which need not be compulsory applied by those who organise it' ([7], p. 30).

These questions over the legitimacy of the IASB influence the long-term survival of the international standard setter in its current form and its ability to grow as a global regulatory body. Indeed, as sharply reported by Nobes and Zeff ([43], p. 281), although it is widely believed that IAS/IFRS have already been adopted in many countries, in nearly all cases what the rules require is a form of convergence at a high level of quality with the IAS /IFRS that might also imply some changes to the IAS/IFRS. In the absence of an overall strong legitimacy, the differences in business, accounting, auditing and regulatory cultures might threaten the growth strategy of the IASB and its long-term survival [44].

In such a scenario, the on-going research for political, substantial and procedural legitimacy stresses the importance that a deliberate marketing strategy can play in the overall global standard setter's business approach. Indeed, in order to overcome the pressures from the external environment (financial turmoil, emergent markets specificities, lobbing from private interests and politicking by public principals), more and various competences are required for the IASB. In particular, some political marketing competences can help the global standard setter in achieving a higher legitimacy and sustainability, as will be discussed in the next paragraph. In fact, even though the translation of commercial marketing theories into the political domain is not straightforward [45,46], many researchers consider political parties as market-driven organisations looking for long-term survival, therefore outlining how marketing literature can contribute in understanding and/or promoting the development of effective political strategies. Hence, by adopting an interdisciplinary interpretative lens, political marketing theories can be useful to explore and explain actual and potential strategies and performance of a specific single-issue organisation, namely a global standard setter-such as the IASB - operating in a global, complex, and political environment. 


\section{Marketing in a Political Environment}

The final aim of marketing strategy is to understand how firms can obtain and sustain a competitive advantage in the long term [47]. This goal is applicable to every kind of organisation that has to operate in a competitive environment where it is necessary to satisfy market needs better than competing organisations do, and to obtain acknowledgment and legitimacy from external stakeholders in an effort to secure long-term survival or superior profitability [48].

With this in place, more recently marketing theoretical frameworks and instruments have been applied to politics with growing sophistication and fervour [49], therefore giving rise to the research discipline of political marketing [50-55]. Political marketing is positioned at the interception of political studies and marketing and 'is about political organisations adapting business-marketing concepts and techniques to help them to achieve their goals' ([45], p. 692). Hence, although there are important differences between traditional marketing fields and politics, literature has shown that the use of the marketing concepts can provide researchers with a solid theoretical framework to investigate and understand the sustainable competitive advantage in the modern politic domain and the performance differentials between parties [49,56].

As observed, the development of political marketing has been driven by the growing adoption of marketing tools and concepts by political actors: mainly, political parties and candidates, but also governments, single-issue groups and lobbying institutions $[46,51,53,56,57]$. In this paper, we contend that political marketing theories and interpretative lenses can be useful to explore and explain actual and potential strategies, as well as the performance, of a specific single-issue organisation, namely a standard setter-such as the IASB — operating in a global, competitive, and political environment.

Indeed, notwithstanding the application of marketing concepts to a standard setter rather than to a political organisation—such as a political party—needs adaptations, several important similarities suggest exploiting the political marketing framework to shed light on IASB's marketing activities and outcomes: firstly, the arguments previously exposed about the globalized and competing environment in which the IASB operates, and the political consequences of its decisions; and, secondly, the analogies existing with regard to the marketing operational tools of the product, promotion, and placement [47]. In this respect, for both political organisations and standard setters, 'product' is mainly represented by ideas and programmes; 'promotion' by conventional and digital media, public relations or events; and 'placement' by local offices and virtual channels (web). Moreover, as for other political parties that offer credence services-as will be discussed in the following - the IASB needs to work on increasing its reputation, and to creating quality and long-time relationships with its market and stakeholders, with the final aim of enhancing the legitimation and sustainability of the institution $[57,58]$.

Hence, on a base of marketing and political marketing theories, we propose a conceptual model, according to which accounting standard setters should also employ and leverage marketing strategies to create value for adopters and to maintain it in the long term. In so doing, the IASB would work to increase its overall legitimacy and sustainability to survive and grow in the long term.

In the following section, we present our conceptual model, explaining its constituting elements and describing why and how they can contribute to the creation of legitimacy and sustainability for a global standard setter.

\section{A Political Marketing Model to Enhance Legitimacy and Sustainability of Private Transnational Organisations}

In order to contribute to filling the gaps that emerged from the literature review, and to explore the role of political marketing strategies in the long-term sustainability of private transnational organisations such as global standard setters, we integrate the theoretical research streams of:

a. Branding management in the political domain, which has analysed the creation of awareness and image for organisations operating in complex and competitive political environments [59]; 
b. Political relationship marketing, which has underlined the importance of the long-term trust and commitment-based relationships for creating value and adapting to a changing environment [56].

In detail, our research question is the following: in which ways may political marketing strategies help a global standard setter, as well as other private transnational organisations, in achieving higher legitimacy, so enhancing their sustainability in the long-term?

In order to answer to our research question, we develop a conceptual model (Figure 1), which identifies the key dimensions to be investigated for understanding the role of political marketing strategies for increasing legitimacy and sustainability of transnational organisations such as global standard setters.

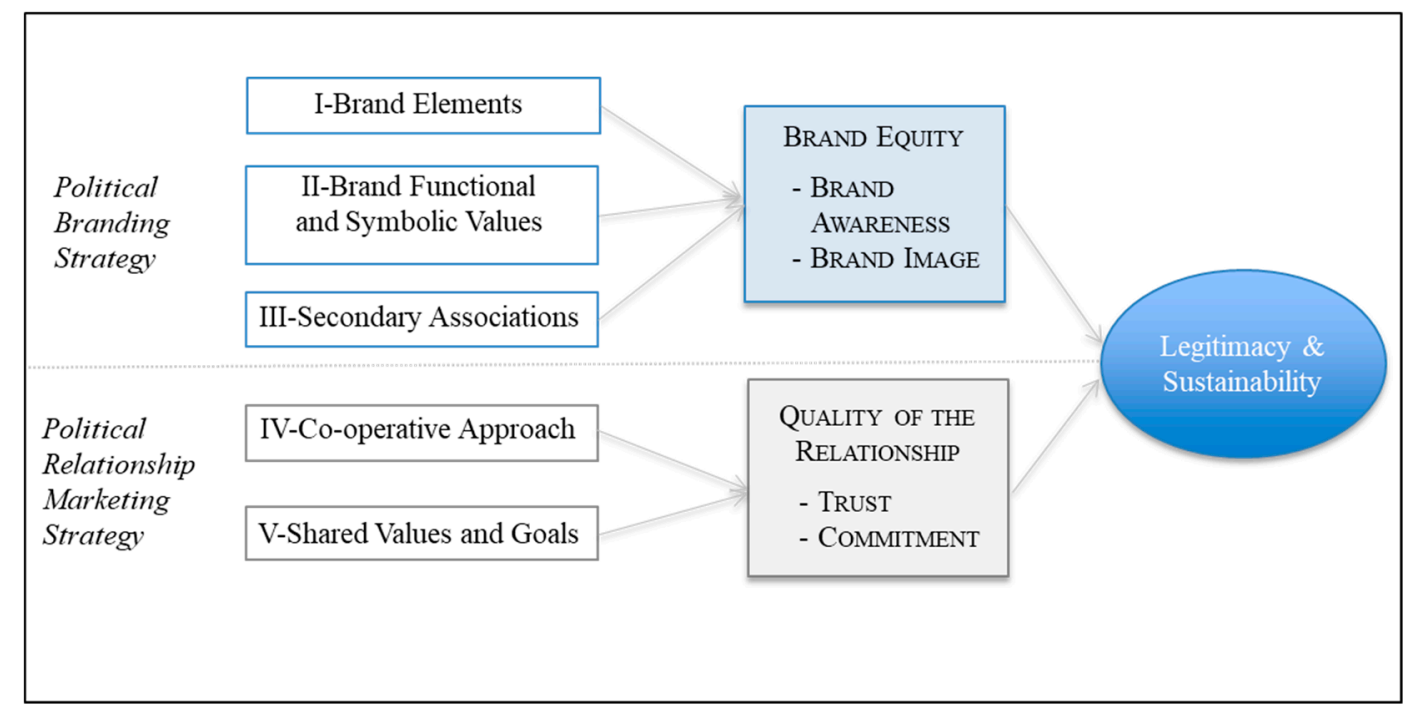

Figure 1. A political marketing model to increase legitimacy and sustainability of private transnational organisations.

The components of our model and their theoretical underpinnings are described below.

\subsection{Branding Management in the Political Domain}

Recent political marketing literature has suggested that brand is a key driver of performance and competitive advantage for political parties, as it is for other market-driven organisations [49,58,59]. Branding is a process involved in the creation of a bundle of symbolic and linguistic elements, which confer a unique identity to a product concept, and which sum up the value-proposition for the customer. Therefore, brands serve valuable functions, such as promising a quality level, reducing risk, engendering trust, and many others. The value accrued by those, and other benefits, is referred to as brand equity [60].

In line with Keller [60], we argue that the value of a brand is a function of its levels of brand awareness and of brand image. Brand awareness is a means through which consumers become acquainted and familiar with a brand and recognize that brand. By contrast, brand image can be defined as 'perceptions about a brand as reflected by the brand association held in consumer memory' ([61], p. 3), which are determined by current marketing policies and by past experiences. Together, they enhance the brand equity, so contributing to the achievement of a competitive advantage and a better performance.

Building a political brand is a very complex activity, since a combination of image, logo, and values can all contribute to a compelling brand narrative [62]. In the context of political marketing, building a political brand awareness is crucial: the choice of parties' logos and symbols, and the implementation of a consistent communication strategy delivered through paid or unpaid media, generate a higher 
awareness and a stronger identity of the political party that lead to higher market share [59]. Indeed, as commercial brands, political parties offer so-called credence services [63], based on the promise to deliver at a future point [64]. At the same time, political parties have to create a strong, positive and unique brand image, through the building and communication of functional as well as symbolic and emotive values associated with the brand $[49,61]$. The symbolic and emotive values, in particular, arise from associations, narratives and cultural values that combine to depict the image of a brand in a consumer's mind. Indeed, an effective management of brand image is fundamental to reduce the uncertainty that typifies the decisional process of so-called customers/citizens, especially in a context-as it is in politics—characterized by immateriality; that is, by selling mainly promises and values (i.e., service contracts ([65], p. 151)), and not physical products [66].

As a political party, a transnational organisation, such as a global standard setter, also mainly sells service contracts and credence services. There is an implicit value-proposition for standard-adopters, which is connected-and not limited - to the quality, the reliability, the fairness and the efficacy of the accounting framework proposed and to the expected positive benefits (at micro and macro levels) engendered by its adoption. In fact, the issue of a new accounting standard determines uncertainty about its intended and, above all, probable unintended economic consequences that cannot be totally foreseen and evaluated by policy-makers and users. Then, as for a political party, a transnational organisation such as a global standard setter needs to increase its legitimacy, also through the enhancement of its brand equity, working on brand awareness and brand image. To do so, the international accounting standard setter should adopt, in a consistent way, the following marketing tools [61]:

I. Defining and promoting brand elements (name, logo, etc.), in order to favour memorability, distinctiveness, transferability, adaptability and legal protection of the brand.

In this case, the standard setter has to adopt in a consistent way its brand (including colour palette and lettering), logo and formats in its official materials and documents (accounting standards and interpretations, books, conference materials).

II. Building brand functional and symbolic values, mainly through promotional and placement activities.

Functional values are related to usefulness and rational attributes, whereas symbolism adds personality and an emotional sense to the brand. For a global standard setter, the functional utility is delivered mainly through the communication of the technical expertise and professional contents of their accounting standards able to meet expressed or latent rationale needs of actual and potential users.

But in order to increase brand awareness and image, it is also necessary to add value to the brand beyond its functional attribute. Along with the technical characteristics of the accounting standards, the transnational organisation has to convey the idea of the basic values that inform its processes and outputs. That includes, for instance, the vision about the organisation's own role, about the future of financial markets or about the main factors affecting wealth, efficiency and stability of the organisations and of the economic environment.

It is important to underline, furthermore, that for building symbolic values, in particular, a segmentation strategy would be required [54]. In fact, identifying the clusters in which the whole market can be divided and describing the homogeneous traits, needs, decision-making processes and expectations of members therein represents a fundamental step to create symbolic attributes that make sense for the selected targets.

III. Building a set of secondary associations in order to promote (or change over time) the notoriety and the signification of a brand.

Organizing events and other activities with various public and private institutions can help to add secondary associations to the global standard setter's brand; in fact, the market would tend to 
associate with the organisation the functional and symbolic values of the other institutions involved in joint programmes and activities. This could help in meeting specific and contingent goals, or in changing the global standard setter's brand values during time, according to the evolution of the external environment and to the specific targets' requests.

\subsection{Political Relationship Marketing}

During the last decades, relationship marketing has become a main topic of political marketing research [57,67-70]. Palmatier ([71], p. 5) defines relationship marketing as the 'process of identifying, developing, maintaining, and terminating relational exchanges with the purpose of enhancing performance'. In particular, literature has shown that political relationship marketing affects the legitimacy and the competitiveness of political actors, therefore influencing the achievement of their final goals [56,72]. Therefore, political parties need to acknowledge the importance of nurturing and developing a variety of relationships as a long-term strategic imperative [73].

In the political domain, the creation of such relationships between citizens and political institutions can be promoted through relationship marketing activities [56].

Therefore, relying on the models of Morgan and Hunt [68], and Henneberg and O'Shaughnessy [56], we examine which are the determinants and the outputs of effective political relationship marketing strategies that can be applied to the context of the accounting standard setters (Figure 1).

The quality of the relationship [71] between the global standard setter and the standard adopters (or other relevant stakeholders) affects the legitimacy of the accounting institution and its performance [56]. Such quality is defined in terms of the level of trust and commitment [68] of the market towards the global standard setter, the goals that such an organisation pursues, the activities that it executes, the values that it embodies and promotes, and the financial markets vision that it wants to put into effect. When the quality of the relationship is high, the legitimation and the reputation of the institution, as well as the value created —as they are perceived by the market—increase, while the perceived risk lowers.

But how is it possible to create trust-based and commitment-based relationships through relationship marketing activities? According to the literature, the main determinants can be:

\section{A co-operative approach.}

The relationship management has to be inspired by a long-term and interactive approach in order to nurture and develop a variety of mutually beneficial relationships. Such an approach should aim at producing a win-win situation, where value is maximized by both 'sellers' and users, and where the users are no longer be considered as passive actors, but as a part actively involved in the process $[53,68,70]$. To achieve these goals, a transnational organisation such a global standard setter should develop competencies in political relationship marketing and routinely carry out initiatives in order to create long-term bonds of reciprocity and legitimacy with external stakeholders, and above all with actual and potential users.

\section{Shared values and goals.}

The creation of trust-based and commitment-based relationships also depends on the capability to share with the market (and, in particular, with the selected targets) a system of common values and goals [58,74]. For this reason, it is important not only to define a coherent set of functional and symbolic attributes (through branding strategies) that fits with the selected targets (both users and other relevant stakeholders), but also to properly and explicitly communicate them. This promotional activity is requested to develop a shared platform of values-as well as of pursued objectives-that represents the common base for mutual comprehension, joint commitment, and for putting efforts towards the same direction. 
The elements of the conceptual model are closely related with each other; in fact, they constitute a network of mutual influence both within a particular strategy and also between them.

For instance, on the basis of the discussion above, it is clear that brand image also affects the quality of the relationships in which the global standard setter is embedded. In fact, brand image contributes in defining the perceived reliability of the accounting standard setter, so clearly affecting the antecedents and the outcomes of the marketing relationship strategy.

Moreover, it is important to underline that the promotional activities represent an operational tool and that they can be effectively managed and meaningfully interpreted only if considered as part of a broader and more complex strategic marketing process. Thus, it is not possible to understand the contribution that marketing can give to the legitimacy and sustainability of a transnational organisation such as a global standard setter, by merely analysing these operational tools while overlooking the whole strategy.

\section{The Case Study of the IASB}

\subsection{Methodology}

In order to advance our knowledge about the role that political marketing strategies can play to reinforce the legitimacy and the sustainability of a transnational organisation such as a global standard setter, we analysed the case of the IASB.

In particular, we conducted an explanatory single case-study [75], which is useful when the researchers are seeking to answer a research question by trying to explain the presumed causal links in real-life interventions [75], as is the case in our study. Therefore, we analysed the activities implemented by the IASB (the real-life interventions), by interpreting them in the light of our proposed conceptual framework (our presumed causal links).

In detail, we collected and analysed printed and on-line documents and secondary information from the IASB. In particular, we made a content analysis of the 61 public speeches performed by the chairman of the IASB (2011-2016), Mr Hans Hoogervorst, and available on the official website of the organisation. The authors analysed the data content by interpreting and identifying emerging themes in theoretical-relevant terms by following a problem-centred setting [76]. We quoted literally the chairman's words to reflect the meaning of the observed phenomena in a deeper way. The main final results of the analysis are synthetized in the next section.

\subsection{Results}

As known, the IASB was established in 2001 and is the standard-setting body of the IFRS Foundation, a private sector, not-for-profit organisation. The mission of the IASB is to develop 'single set of high quality global accounting standards that provide high quality transparent and comparable information in general purpose financial statements'.

The IASB has always attempted to compensate for its lack of legal legitimacy by enhancing its substantial and procedural legitimacy. However, the increasing complexity of the environment in which the IASB operates makes the legitimacy building process a never-ending struggle, suggesting the IASB also adopts political marketing strategies.

The case study analysis provides interesting insights about the political marketing activities implemented so far by the IASB to strengthen its legitimacy and sustainability. Our main results will be discussed below with reference to the different sections of our conceptual framework.

I. Defining and promoting brand elements (name, logo, etc.), in order to favour memorability, distinctiveness, transferability, adaptability and legal protection of the brand.

Concerning such an issue, an analysis of the current IASB's physical and digital materials shows a coherent use of its brand elements. Indeed, the IASB's brand (logo, colour, lettering, formats, etc.) is used in a consistent way in all its official printed and on-line materials and documents. 
II. Building brand functional and symbolic values, mainly through promotional and placement activities.

As to this point, the IASB routinely carries out communication and distribution activities that are useful to achieve this goal, such as conferences and workshops, events for IFRS teachers, IFRS implementation sessions and investor-focused IFRS updates.

In addition, the analysis of public speeches given by the chairman of the IASB, Mr Hans Hoogervorst, shows anecdotal evidence about the attempt to give the IASB brand functional and symbolic values and to communicate them, as it can be observed in the extracts below:

'It is important to understand that the full benefits of using the IFRS-brand can only be enjoyed if you adopt it fully. ( . . ) Most jurisdictions have concluded that the credibility bonus of full adoption of IFRS outweighs the temptation to tinker with the standard to address local problems. ( ... ). Although the office of the IASB is located very close to the Tower of London, my organisation itself is certainly not an ivory tower. We have a dynamic, highly motivated staff recruited from all over the world' [77].

' (... ) Preceding misconceptions have led to a third persistent myth, namely that IFRSs are only of use to the financial whizz-kids in London and Wall Street. This myth holds that our standards are incompatible with the culture of countries with a strong manufacturing tradition. Again, this is not true. ( . . . ) A final myth I want to touch upon is that the IASB is sometimes perceived to be an ivory tower, dominated by Anglo Saxons in far-away London. Indeed, the IASB is not a foreign organisation but a truly international one. ( . . ) We only have one mission: to develop high quality accounting standards that serve our constituents around the world' [78].

'Our accountability to the Monitoring Board gives additional assurances that the IASB is not a free-floating ivory tower, which we, of course, never were. At the same time, this multilateral body of securities regulators has reinforced the independence of the IASB from undue lobbying from any single jurisdiction' [79].

III. Building a set of secondary associations in order to promote (or change during time) the notoriety and the signification of a brand.

Regarding this issue, it is worth mentioning as an example an agreement formalized by the IASB with the International Integrated Reporting Council (IIRC) in 2013. This agreement was aimed at deepening the cooperation between the two organisations on the IIRC's work to develop an integrated corporate reporting framework. According to the declarations of the two organisations, the specific objective of the agreement was creating a new corporate reporting language able to better serve businesses and investors, and so contributing to a more sustainable global economy. Therefore, through the co-branding of the two organisations, the IASB tried to attach a secondary association to its brand; creating the conditions for a better language for businesses to communicate with their investors is a way not only to deliver more sustainable value creation and more efficient capital markets, but also a more sustainable global economy.

Other examples of the attempt by the IASB to build a set of secondary order associations with the brand emerge from the following words of the chairman of the IASB:

'( ... ) The increasing awareness that environmental and societal restrictions have an impact on long-term value creation is also clear. The Financial Stability Board's establishment of the Task Force on Climate-related Financial Disclosures is a notable example of this trend. ( ... ) The Board is currently looking at the question of whether we should update our Practice Statement to reflect these new developments. I think we have reason to do so. We are especially well-placed to make sure there is a good fit and connectivity between financial reports and non-financial information, which I believe to be essential to the success of integrated reporting' [80]. 


\section{A co-operative approach.}

The IASB's formal due process can be interpreted as an important instrument for an implementation of the co-operative approach. Moreover, in order to strengthen bidirectional relationships, the IASB proposes further engagement activities such as individual meetings with organisations or representative bodies, and live webcasts with interactive question and answer sessions or online surveys. The IASB has also recently introduced a specific channel for dialogue with another stakeholder category, namely the research community, launching the IFRS Research Centre. This initiative is designed to support the establishment of a dedicated research capability that relies on the combination of internal and external intellectual resources.

The words of Mr Hoogervorst seem to support the attention of the IASB towards a co-operative approach with external stakeholders, as the quotations below show:

'Almost all jurisdictions that adopt our standards experience some challenges with adjusting domestic accounting practices to IFRS. That is to be expected. Often these problems can be resolved, sometimes it is more difficult, such as is the case with the issue of land rights in Indonesia. ( . . . ) Chances are that other jurisdictions are also having the same problems, so it is much better that we work together, to fix the problem centrally so that all IFRS adopters can benefit from such improvements. ( . . . . We are open to views from all over the world. We need you, just as much as you need us' [77].

'We will continue to strengthen the IASB's institutional relationships in a way that respects and enhances the independence of the standard-setting process. By that, I mean to deepen our engagement with those around the world who are impacted by our work, and to ensure that they have a sense of ownership and respect for the product that we are developing for investors globally' [81].

'We will continue to increase the sense of trust and buy-in among those who have adopted our standards. We will continue to strengthen the institutional relationships between the IASB and Europe, in the same way as we are doing in other parts of the world. That is how we, as an independent standard-setter, must reciprocate your trust' [82].

'We are determined to further invest our relationship with investors, to ensure we get more balanced feedback on our proposals than currently is the case. We are especially interested in strengthening our relations with what I would like to call our "end-users"' [83].

Recently, the IASC Foundation opened an Asia-Oceania regional office (based in Tokyo), one the most interesting markets for the IASB, in order to support greater regional outreach and participation in the IASB's standard setting process. This could be interpreted as a placement policy intended to get closer to its targets, also through a physical proximity, and eventually to promote an easier and quicker co-operative dialogue.

V. Shared values and goals.

Our anecdotal evidence shows that the IASB seems to acknowledge the importance of the creation of shared values and goals, as it emerges in the following public speeches by Mr Hoogervorst:

'When I was elected Chair of the IASB, I said that I have investor protection in my DNA. Clearly, the US is in the DNA of the IASB ( ... ). All of us here today-whether we write accounting standards, prepare financial statements, verify the integrity of financial statements or study the numbers to understand the performance of a commercial enterprise-are part of a global effort that underlies free trade and free-flowing capital. The entire IASB take our responsibilities in this endeavour extremely seriously. It is important for investor protection 
in the US and internationally that the SEC remains at the forefront of determining financial reporting policy. This cannot be done from afar. We need the United States to remain on board. We count on your commitment and you can count on ours' [84].

'It is always a pleasure to be here in Washington, because believe it or not, Washington is the birthplace of the IASB' [85].

\section{Conclusions, Limitations and Implications for Theory and Practice}

The private transnational governance of the IASB represents the Achilles' heel of the standard setter exposed to a complex environment, since the absence of political legitimacy undermines its long-term survival and growth. The IASB has always been aware of the need to compensate for its lack of legal legitimacy through its technical expertise (substantial legitimacy) and the implementation of transparent and formal due process (procedural legitimacy). However, with the increasing relevance and influence of the IASB as an emerging global standard setter, substantial and procedural legitimacy should also be reinforced by the leverage of political marketing competencies.

In this scenario, our proposed conceptual political marketing model explains how the adoption of branding strategies and relationship marketing strategies can drive private transnational organisations to higher legitimacy and sustainability. We contend that a transnational organisation such as a global standard setter, including the IASB, should systematically and consistently implement marketing tools in order to increase its brand equity in terms of brand awareness and brand image. At the same time, such organisations have to invest in relationship marketing strategies to enhance the quality of the relationships (in terms of trust and commitment) with users and other external stakeholders, through the creation of shared values and goals and the establishment of a co-operative approach.

This study also presents some limitations that have to be taken into account when evaluating its results. Above all, our empirical analysis only relies on documents and secondary data that are available to the public. To achieve a deeper understanding of this topic, further analysis should also collect data through direct interviews with key informants of the IASB. Moreover, we perform an explanatory case study, which is idiosyncratic in nature; therefore, by adopting our proposed conceptual model, future study should assess the extent to which our results can be extended to other transnational organisations, through the examination of different case studies.

Notwithstanding such limitations, we make a contribution both to theory and practice. This paper draws together political branding theory and political relationship marketing, and incorporates them into a conceptual framework that makes a contribution to understanding how transnational organisations, such as global standard setters, can enhance their legitimacy and sustainability thanks to political marketing strategies. To the best of our knowledge, this is the first attempt to analyse the strategies of transnational organisations by drawing on political marketing literature. We therefore contribute to an interdisciplinary debate that so far has recognized the efforts done by accounting standard setters to increase their legitimacy and sustainability in the long-term, but by adopting other interpretative lenses (technical, juridical, etc.). Instead, we discuss in our paper how, after making the necessary adaptations, several important similarities suggest exploiting the political marketing framework to shed light on such topics.

This paper also makes a contribution to the political marketing literature, since only recent studies have introduced branding theory into the political marketing debate [58]. Moreover, the results of our study can be the basis for future explorative or explicative empirical analysis in this interesting setting of research at the intersection of different disciplines.

Furthermore, the results of our empirical analysis in the case of the IASB highlight the activities implemented by the organisation that can be interpreted in the light of our conceptual model, in so discussing what has been done so far by the organisation to strengthen its legitimacy through political marketing activities. The implications of our models can be useful to suggest political marketing strategies to be implemented in the future in order to increase the legitimacy and the sustainability in the long-term of the IASB, as well as of other private transnational organisations. 
Author Contributions: B.M. conceptualized the framework of the article, contributed to the literature review, developed the methodology, analysed the results, prepared the conclusions and supervised the teamwork. N.M. conceptualized the framework of the article, contributed to the literature review and prepared the conclusions. P.F. contributed to the literature review, was responsible for collecting and processing data for the case study and reviewed the paper.

Funding: This research received no external funding.

Acknowledgments: We acknowledge the two anonymous reviewers for their precious comments and suggestions. For the publication of this article, we would also like to thank the 'VALERE program' of the University of Campania 'Luigi Vanvitelli' that assigns contributions for the diffusion of open access research products.

Conflicts of Interest: The authors declare no conflict of interest.

\section{References}

1. Buchanan, A.; Keohane, R. The legitimacy of global governance institutions. Ethics Int. Aff. 2006, 20, 405-437. [CrossRef]

2. Held, D.; Archibugi, M.K. Global Governance and Public Accountability; Blackwell: Oxford, UK, 2005.

3. Black, J. Constructing and contesting legitimacy and accountability in polycentric regulatory regimes. Regul. Gov. 2008, 2, 137-164. [CrossRef]

4. Bengtsson, E. Repoliticalization of accounting standard setting-The IASB, the EU and the global financial crisis. Crit. Perspect. Account. 2011, 22, 567-580. [CrossRef]

5. Nolke, A. The politics of accounting regulation: Responses to the subprime crisis. In Global Finance in Crisis: The Politics of International Regulatory Change; Helleiner, E., Pagliari, S., Zimmermann, H., Eds.; Routledge: London, UK, 2011; pp. 37-55.

6. Bischof, J.; Brüggemann, U.; Daske, H. Fair Value Reclassifications of Financial Assets during the Financial Crisis; Working Paper; Humboldt-Universität zu Berlin: Berlin, Germany, 2011.

7. Burlaud, A.; Colasse, B. International accounting standardisation: Is politics back? Account. Eur. 2011, 8, 23-47. [CrossRef]

8. Warnock, K. Structure and argument in accounting standards. Account. Bus. Res. 1992, 22, 179-188. [CrossRef]

9. Young, J. Constructing, persuading and silencing: The rhetoric of accounting standards. Account. Org. Soc. 2003, 28, 621-638. [CrossRef]

10. Masocha, W.; Weetman, P. Rhetoric in standard setting: The case of the going concern audit. Account. Audit. Account. J. 2007, 20, 74-100. [CrossRef]

11. Savigny, H. Political Marketing. In The Oxford Handbook of British Politics; Flinders, M., Gamble, A., Hay, C., Kenny, M., Eds.; Oxford University Press: Oxford, UK, 2009.

12. Sunder, S. Political economy of accounting standards. J. Account. Lit. 1988, 7, 31-41.

13. Stigler, G. The theory of economic regulation. Bell J. Econ. Manag. Sci. 1971, 2, 3-21. [CrossRef]

14. Posner, R.A. Theories of economic regulation. Bell J. Econ. Manag. Sci. 1974, 5, 335-358. [CrossRef]

15. Bushman, R.; Landsman, W.R. The pros and cons of regulating corporate reporting: A critical review of the arguments. Account. Bus. Res. 2010, 40, 259-273. [CrossRef]

16. Johnson, S.B.; Solomons, D. Institutional legitimacy and the FASB. J. Account. Public Policy 1984, 3, $165-183$. [CrossRef]

17. Wallace, R.S.O. Survival strategies of a global organization: The case of the International Accounting Standards Committee. Account. Horiz. 1990, 4, 1-22.

18. Schmidt, M. On the legitimacy of accounting standard setting by privately organized institutions in Germany and Europe. Schmalenbach Bus. Rev. 2002, 54, 171-193. [CrossRef]

19. Danjou, P.; Walton, P. The legitimacy of the IASB. Account. Eur. 2012, 9, 1-15. [CrossRef]

20. Zeff, S.A. The evolution of the IASC into the IASB, and the challenges it faces. Account. Rev. 2012, 87, 807-837. [CrossRef]

21. Camfferman, K.; Zeff, S.A. Financial Reporting and Global Capital Markets: A History of the International Accounting Standards Committee, 1973-2000; Oxford University Press: Oxford, UK, 2007.

22. Heem, G. International Accounting Standardization: The Institutional Legitimacy of the Private Standard Setter. Available online: http:/ / hal.archives-ouvertes.fr (accessed on 17 April 2018). 
23. Richardson, A.J.; Eberlein, B. Legitimating transnational standard-setting: The case of the International Accounting Standards Board. J. Bus. Ethics 2011, 98, 217-245. [CrossRef]

24. International Accounting Standards Board. Framework for the Preparation and the Presentation of Financial Statement; IASC Board: London, UK, 1989.

25. Hines, R.D. Financial accounting knowledge, conceptual framework projects and the social construction of the accounting profession. Account. Audit. Account. J. 1989, 2, 72-92. [CrossRef]

26. Peasnell, K.V. The function of a Conceptual Framework for corporate financial reporting. Account. Bus. Res. 1982, 12, 243-256. [CrossRef]

27. Dopuch, N.; Sunder, S. FASB's statement on objectives and elements of financial accounting: A review. Account. Rev. 1980, 55, 1-21.

28. Page, M.; Spira, L. The conceptual underwear of financial reporting. Account. Audit. Account. J. 1999, 12, 489-501. [CrossRef]

29. Le Manh-Béna, A.; Ramond, O. Determining a consistent set of accounting and financial reporting standards: A research note based on the IASB-FASB Conceptual Framework revision project. In 32ème Congrès de l'AFC; HAL: Montpellier, France, 2011.

30. IFRS Foundation. Constitution; Trustees: London, UK, 2013.

31. IFRS Foundation. IASB and IFRS Interpretations Committee due Process Handbook; Trustees: London, UK, 2013.

32. Büthe, T.; Mattli, W. Assessing the IASB. Working Paper. 2008. Available online: globaleconomicgovernance. org (accessed on 22 April 2018).

33. Lloyd, R.; Oatham, J.; Hammer, M. Global Accountability Report; One World Trust: London, UK, 2007.

34. Perry, J.; Nölke, A. The political economy of international accounting standards. Rev. Int. Political Econ. 2006, 13, 559-586. [CrossRef]

35. Botzem, S. Transnational expert-driven standardization: Accountancy governance from a professional point of view. In Transnational Private Governance and Its Limits; Graz, J.C., Nölke, A., Eds.; Routledge: London, UK; New York, NY, USA, 2007; pp. 44-57.

36. Mattli, W.; Büthe, T. Accountability in accounting? The politics of private rule-making in the public interest. Governance 2005, 18, 399-429. [CrossRef]

37. Colasse, B.; Pochet, C. The genesis of the 2007 Conseil National de la Comptabilitè: A case of institutional isomorphism? Account. Eur. 2009, 6, 25-55. [CrossRef]

38. Veron, N. The Global Accounting Experiment; Bruegel: Brussels, Belgium, 2007.

39. Kerwer, D. How accountable is the International Accounting Standards Board? In Proceedings of the 6th SGIR Pan-European Conference in International Relations, Turin, Italy, 12-15 September 2007.

40. Suchman, M. Managing legitimacy: Strategic and institutional approaches. Acad. Manag. Rev. 1995, 20, 571-610. [CrossRef]

41. Jorrisen, A.; Lybaert, N.; Orens, R.; Van Der Tas, L. Formal participation in the IASB's due process of standard setting: A multi-issue/multi-period analysis. Eur. Account. Rev. 2012, 21, 693-729. [CrossRef]

42. Le Manh-Béna, A. Le Processus de Normalisation Comptable par l'IASB: Le cas du Résultat. Ph.D. Thesis, CNAM, Paris, France, 2009.

43. Nobes, C.W.; Zeff, S.A. Auditors' affirmation of compliance with IFRS around the world: An exploratory study. Account. Perspect. 2008, 7, 279-292. [CrossRef]

44. Zeff, S.A. Some obstacles to global financial reporting comparability and convergence at a high level of quality. Br. Account. Rev. 2007, 39, 290-302. [CrossRef]

45. Lees-Marshment, J. The marriage of politics and marketing. Political Stud. 2001, 49, 692-713. [CrossRef]

46. Scammell, M. Political brands and consumer citizens: The rebranding of Tony Blair. Ann. Am. Acad. Political Soc. Sci. 2007, 611, 176-192. [CrossRef]

47. Kotler, P. Marketing Management, 7th ed.; Prentice-Hall: Englewood Cliffs, NJ, USA, 1991.

48. Day, G.S. The capabilities of market-driven organizations. J. Mark. 1994, 58, 37-52. [CrossRef]

49. O'Cass, A.; Voola, R. Explications of political market orientation and political brand orientation using the resource-based view of the political party. J. Mark. Manag. 2011, 27, 627-645. [CrossRef]

50. Reid, D.M. Marketing the political products. Eur. J. Mark. 1988, 22, 34-47. [CrossRef]

51. O'Shaughnessy, N. The Phenomenon of Political Marketing; Macmillan: London, UK, 1990.

52. O'Cass, A. Political marketing and the marketing concepts. Eur. J. Mark. 1996, 30, 45-61. [CrossRef]

53. Newman, B.I. Handbook of Political Marketing; SAGE Publications: New York, NY, USA, 1999. 
54. Baines, P.R.; Worcester, R.M.; Jarrett, D.; Mortimore, R. Market segmentation and product differentiation in political campaigns: A technical feature perspective. J. Mark. Manag. 2003, 19, 225-249. [CrossRef]

55. Smith, G. Positioning political parties: The 2005 UK general election. J. Mark. Manag. 2005, 21, 1135-1149. [CrossRef]

56. Henneberg, S.C.; O'Shaughnessy, J. Political relationship marketing: Some macro/micro thoughts. J. Mark. Manag. 2009, 25, 5-29. [CrossRef]

57. Lees-Marshment, J. Political Marketing. In Principles and Applications, 2nd ed.; Routledge: New York, NY, USA, 2014.

58. Winther Nielsen, S. On political brands: A systematic review of the literature. J. Political Mark. 2015, 16, 118-146. [CrossRef]

59. Reeves, P.; de Chernatony, L.; Carrigan, M. Building a political brand: Ideology or voter driven strategy. J. Brand Manag. 2006, 13, 418-428. [CrossRef]

60. Keller, K.L. Strategic Brand Management: Building, Measuring, and Managing Brand Equity, 2nd ed.; Prentice-Hall: Upper Saddle River, NJ, USA, 2003.

61. Keller, K.L. Conceptualizing, measuring, and managing customer-based brand equity. J. Mark. 1993, 57, 1-22. [CrossRef]

62. Dean, D.; Croft, R.; Pich, C. Toward a conceptual framework of emotional relationship marketing: An examination of two UK political parties. J. Political Mark. 2015, 14, 19-34. [CrossRef]

63. Mahajan, V.; Wind, Y. Got emotional product positioning? Mark. Manag. 2002, 11, 36-41.

64. Smith, G.; Speed, R. Cultural branding and political marketing: An exploratory analysis. J. Mark. Manag. 2011, 27, 1304-1321. [CrossRef]

65. Newman, B.I. The Marketing of the President: Political Marketing as Campaign Strategy; SAGE Publications: Thousand Oaks, CA, USA, 1994.

66. Normann, R. Service Management. In Strategy and Leadership in Service Businesses; Wiley: New York, NY, USA, 1984.

67. Grönroos, C. From marketing-mix to relationship marketing: Towards a paradigm shift in marketing. Manag. Decis. 1994, 32, 4-20. [CrossRef]

68. Morgan, R.M.; Hunt, S.D. Relationship-based competitive advantage: The role of relationship marketing in marketing strategy. J. Bus. Res. 1994, 46, 281-290. [CrossRef]

69. Iacobucci, D. Networks in Marketing; SAGE Publications: Thousand Oaks, CA, USA, 1996.

70. Vargo, S.L.; Lusch, R.F. Evolving to a new dominant logic for marketing. J. Mark. 2004, 68, 1-17. [CrossRef]

71. Palmatier, R.W. Relationship Marketing; Marketing Science Institute: Cambridge, MA, USA, 2008.

72. Ormrod, R.P.; Savigny, H. Political market orientation: A framework for understanding relationship structures in political parties. Party Politics 2012, 18, 487-502. [CrossRef]

73. Bannon, D.P. Relationship marketing and the political process. J. Political Mark. 2005, 4, 73-90. [CrossRef]

74. Nahapiet, J.; Ghoshal, S. Social capital, intellectual capital and the organizational advantage. Acad. Manag. Rev. 1998, 23, 242-266. [CrossRef]

75. Yin, R.K. Case Study Research: Design and Methods, 3rd ed.; Sage Publications: Beverly Hills, CA, USA, 2003.

76. Corley, K.G.; Gioia, D.A. Building theory about theory building: What constitutes a theoretical contribution? Acad. Manag. Rev. 2011, 36, 12-32. [CrossRef]

77. Hoogervorst, H. IFRS and Indonesian Accounting Standards 2013 and Beyond. IAI-AFA International Seminar. Indonesia, 6 March 2013. Available online: http:/ / archive.ifrs.org/The-organisation/Membersof-the-IASB /IASB-speeches/Documents /2013/Hans-Hoogervorst-Indonesia-Speech-March-2013.pdf (accessed on 19 January 2018).

78. Hoogervorst, H. Dispelling Myths about IFRS: Introductory Remarks. Tokyo, Japan, 15 November 2012. Available online: http:/ / archive.ifrs.org/Alerts/PressRelease/Documents/2012/Dispelling-myths-aboutIFRS-Hans-Hoogervorst-2012.pdf (accessed on 18 January 2018).

79. Hoogervorst, H. Are We There yet? Charting the World's Progress towards Global Accounting Standards. Hong Kong, 5 June 2013. Available online: http: / / archive.ifrs.org/The-organisation/Members-of-the-IASB/ IASB-speeches/Documents/2013/Hans-Hoogervorst-speech-June-2013.pdf (accessed on 19 January 2018).

80. Hoogervorst, H. The IASB and Integrated Reporting. IIRC Council Meeting. New York, 26 April 2017. Available online: http:/ / archive.ifrs.org/About-us/IASB/Members/Documents/hans-hoogervorstintegrated-reporting-april-2017.pdf (accessed on 24 January 2018). 
81. Hoogervorst, H. China and IFRS: An Opportunity for Leadership in Global Financial Reporting. Beijing, 7 July 2011. Available online: http:/ / archive.ifrs.org/News / Announcements-and-Speeches/Documents / HansHoogervorstBeijingJuly2011.pdf (accessed on 17 January 2018).

82. Hoogervorst, H. Speech to European Parliament ECON Committee. Brussels, 3 October 2011. Available online: http:/ / archive.ifrs.org/Alerts/Conference/Documents/HHoogervorst-ECON-speech-October2011.pdf (accessed on 17 January 2018).

83. Hoogervorst, H. The Imprecise World of Accounting. IAAER Conference. Amsterdam, 20 June 2012. Available online: http://archive.ifrs.org/Alerts/Conference/Documents/ HHoogervorstJune2012theimpreciseworldofaccounting.pdf (accessed on 18 January 2018).

84. Hoogervorst, H. Speech at the AICPA Conference on Current SEC and PCAOB Developments. AICPA Conference. Washington, 6 December 2011. Available online: http:/ / archive.ifrs.org/Alerts /Conference/ Pages/Hans-Hoogervorst-AICPA-Conference-SEC-and-PCAOB.aspx (accessed on 17 January 2018).

85. Hoogervorst, H. Speech at the AICPA Conference on Current SEC and PCAOB Developments. AICPA Conference. Washington, 10 December 2013. Available online: http:/ / archive.ifrs.org/Alerts/Conference/ Documents / 2013/Hans-Hoogervorst-AICPA-SEC-speech-December-2013.pdf (accessed on 19 January 2018).

(C) 2018 by the authors. Licensee MDPI, Basel, Switzerland. This article is an open access article distributed under the terms and conditions of the Creative Commons Attribution (CC BY) license (http:/ / creativecommons.org/licenses/by/4.0/). 